\title{
The New Influenza A Virus: A/Mexico/2009 (H1N1): Practice Point for Caregivers of Children and Youth
}

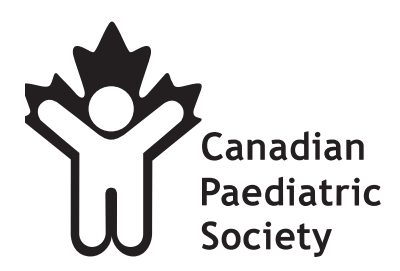

Français en page 338 new H1N1 influenza A virus of swine origin
(A/Mexico/2009 [H1N1]) that causes respiratory dis-
ease in humans was first reported in early April 2009. By early
May, countries had reported a total of almost 1,000 confirmed
cases to the World Health Organization, with the majority
reported in Mexico. Serious illness and deaths have occurred in children and youth as well as in adults, although to date the vast majority of severe cases have been in Mexico. The purpose of this Paediatric Infectious Disease Note is to provide a brief overview of: 1) the clinical manifestations; 2) the epidemiology; 3) diagnostic tests; 4) treatment; and 5) prevention and control measures for A/Mexico/2009 (H1N1).

\section{Congenital syphilis: No longer just of historical interest}

$\mathrm{T}$ The majority of paediatricians and family physicians in practice in Canada today have never seen a case of congenital syphilis. However, there have been outbreaks of syphilis across Canada since 2001, such that the incidence of syphilis in Canada in 2007 was projected to be almost 10-fold compared with what it was in 1994 to 2000. The initial increase in incidence was concentrated in men who have sex with men, but heterosexual transmission in inner- city populations now accounts for a large percentage of cases in some provinces. The incidence of syphilis in 2007 was highest in British Columbia and Alberta, followed by Quebec and Ontario. This has led to an increase in reported congenital cases from approximately two per year to 10 per year nationally; it is likely that other cases have been missed because infants are asymptomatic or the diagnosis has not been considered.

For the complete version of this practice point and references, please visit www.cps.ca/English/publications/InfectiousDiseases.htm

\section{INFECTIOUS DISEASES AND IMMUNIZATION COMMITTEE}

Members: Drs Robert Bortolussi, IWK Health Centre, Halifax, Nova Scotia (chair); Jane Finlay, Richmond, British Columbia; Joan L Robinson, Edmonton, Alberta; Élisabeth Rousseau-Harsany, Sainte-Justine UHC, Montreal, Quebec (board representative); Lindy M Samson, Children's Hospital of Eastern Ontario, Ottawa, Ontario

Consultants: Drs Noni E MacDonald, IWK Health Centre, Halifax, Nova Scotia; Dorothy L Moore, The Montreal Children's Hospital, Montreal, Quebec

Liaisons: Drs Upton D Allen, The Hospital for Sick Children, Toronto, Ontario (Canadian Pediatric AIDS Research Group); Charles PS Hui, Children's Hospital of Eastern Ontario, Ottawa, Ontario (CPS Liaison to Health Canada, Committee to Advise on Tropical Medicine and Travel); Nicole Le Saux, Children's Hospital of Eastern Ontario, Ottawa, Ontario (Immunization Program, ACTive); Larry Pickering, Elk Grove, Illinois, USA (American Academy of Pediatrics); Marina I Salvadori, Children's Hospital of Western Ontario, Ottawa, Ontario (CPS Liaison to Health

Canada, National Advisory Committee on Immunization)

Correspondence: Canadian Paediatric Society, 2305 St Laurent Boulevard, Ottawa, Ontario K1G 4J8. Telephone 613-526-9397, fax 613-526-3332, Web sites www.cps.ca, www.caringforkids.cps.ca 